\title{
Sources of contaminants and groundwater quality in the coastal part of a river delta
}

\author{
E. Vetrimurugan $\cdot$ L. Elango $\cdot$ N. Rajmohan
}

Received: 11 February 2012/Revised: 21 June 2012/ Accepted: 11 November 2012/Published online: 8 January 2013

(c) CEERS, IAU 2012

\begin{abstract}
Assessment of possible sources that control the groundwater quality was carried out in the Cauvery deltaic region, India, since domestic and agricultural water requirements are largely met by groundwater abstraction. Major ion and bromide contents are high in groundwater in the coastal wells. Spatial and vertical distributions of ions reveal that the shallow wells and wells in coastal parts have high chloride, nitrate, ammonium and phosphate. Groundwater quality assessment was carried out using the prescribed limits of World Health Organization and Bureau of Indian Standards which indicates that $55 \%$ of samples are not fit for drinking. Integrated suitability map for drinking was created based on the concept that if the water sample exceeds any one of the standards by World Health Organization or Bureau of Indian Standards, the well is not fit for drinking. Groundwater quality for agricultural activities was assessed using electrical conductivity, sodium adsorption ratio, residual sodium carbonate, United States salinity laboratory diagram and Food and Agricultural Organization methods. According to Food and Agricultural Organization,
\end{abstract}

E. Vetrimurugan

Department of Civil Engineering,

M.A.M. College of Engineering and Technology,

Tiruchirapalli 621 105, Tamil Nadu, India

L. Elango $(\square)$

Department of Geology, Anna University,

Chennai 600 025, Tamil Nadu, India

e-mail: elango@annauniv.edu

N. Rajmohan

Raj Geo-Environmental Consultants,

Madambakkam, Chennai 600072 ,

Tamil Nadu, India
$84 \%$ of samples are classified as low sodium water and are suitable for all crops and soils. It was found that the water quality in this area is affected by improper disposal of waste, sewage/drainage canals near the wells, irrigation return flow, application of agrochemicals and saline water intrusion in the coastal region. Further, integrated suitability map produced in this study will be useful for future groundwater development and planning in this area. The suitability map needs to be updated periodically for proper management plan to preserve the groundwater resource in this region.

Keywords Agriculture $\cdot$ Contamination $\cdot$ Irrigation water quality · Unconfined aquifer

\section{Introduction}

Studies on groundwater quality have received greater importance in recent decades because of increased use of this reserve for various purposes in several parts of the world. Groundwater quality is largely affected by natural and human activities. According to UNESCO (2007) report, $80 \%$ of the diseases and deaths in the developing countries are related to water contamination. In the coastal region, saline water intrusion due to over pumping, seaspray and marine aerosols deposited on the topsoil are the major sources of deterioration of groundwater quality (Banner et al. 1989; Rosenthal et al. 1992; Vengosh and Rosenthal 1994). Likewise, anthropogenic contamination such as irrigation return flow, agro chemicals, domestic sewage, septic tank effluent and animal wastes are other major sources of contamination of groundwater. Numerous studies have quantified the effect of anthropogenic contamination in groundwater composition (Brink et al. 
2007; Kumar et al. 2009; Lang et al. 2011; Vijay et al. 2011). Recharge from the agricultural field is one of the main sources of nutrients and salinity in the groundwater. Groundwater containing nitrate and nitrite above the permissible limit is not suitable for drinking (Lee et al. 2003; Rajmohan and Elango 2005). Fluorosis caused by elevated fluoride concentration in drinking water has been reported in various countries such as India (Shortt et al. 1937; Ayoob and Gupta 2006; Brindha et al. 2011), China (Wang and Huang 1995), Tanzania (Mjengera and Mkongo 2003), Mexico (Diaz-Barrigo et al. 1997), Argentina (Kruse and Ainchil 2003) and South Africa (WRC 2001). Intake of water containing excess fluoride causes different types of fluorosis, primarily dental and skeletal fluorosis (ICPS 2002). Land use pattern also has strong relationship with groundwater contamination as reported by Jeong (2001), Elhatip et al. (2003) and Rajmohan et al. (2009).

Agriculture is one of the activities for economic development in most of the countries and groundwater quality criterion is important to decide on the suitability of water for irrigation. Several researchers have assessed the groundwater quality for domestic and agricultural activities using various parameters such as sodium absorption ratio (SAR), residual sodium carbonate (RSC), Unites States salinity laboratory (USSL) classifications, etc. (Subramani et al. 2005; Jeevanandam et al. 2006; AlFutaisi et al. 2007; Pritchard et al. 2008; Sivakumar and Elango 2008; Jalali 2009; Ma et al. 2009; Tank and Chandel 2010; Dar et al. 2011; Kamble and Vijay 2011; Pant 2011; Ramesh and Elango 2011; Brindha and Elango 2011). These studies emphasized that groundwater quality monitoring and evaluation are necessary to take necessary action to protect the groundwater for its sustainable management.

Tamil Nadu state was India's fifth biggest producer of rice (IRRI 2007). In Tamil Nadu, the total cultivated area was 56.10 million hectares in 2007-2008. Out of the entire state, the deltaic region of Cauvery River alone produces large quantity of rice. In fact the Cauvery delta region is known as the Rice Bowl of South India. Water requirements for domestic and agricultural use in this region are partly met by groundwater abstraction because of lack of surface water as the Cauvery River is a nonperennial river and due to frequent failure or untimely monsoonal rains. Hence, assessment of groundwater quality and possible contamination sources is inevitable to safeguard this resource. This study was carried out with an objective of assessing the groundwater quality and sources of contamination in the deltaic region of Cauvery River, Tamil Nadu, India, as groundwater is the major source of water for agricultural and domestic purposes in this region.
Study area

The study area (about 850 sq. $\mathrm{km}$ ) forms a part of deltaic region of Cauvery River basin, Tamil Nadu (Fig. 1). The region enjoys a tropical monsoon climate, with mean temperature ranging from 25 to $32{ }^{\circ} \mathrm{C}$, relative humidity from 60 to $70 \%$ and the average rainfall of about $1,200 \mathrm{~mm} /$ year. Being a coastal region, it is prone to frequent catastrophic cyclones and floods. The region was also severely affected by the 2004 tsunami (Rajamanickam et al. 2006; Sivakumar and Elango 2010). It receives high intensity of rainfall during north-east monsoon (OctoberDecember), moderate during south-west monsoon (JulySeptember) and low during transitional period. Cauvery is the main river flowing towards the sea in the area and it has ten main tributaries namely Nandalar, Nattar, Vettar, Arasalar, Mudikondan, Thirumalairajanar, Chozha chudamani, Puttar, Nandaar and Puravadayanar. These rivers are non-perennial and flow generally for a few days during the monsoons during October-December. The rural population mostly depends on the use of groundwater for cultivation and domestic uses during most period of the year. The common crops grown in this area are rice, sugarcane, cotton, grams and tobacco.

\section{Geology and hydrogeology}

The study area is generally flat with maximum elevation of $4 \mathrm{~m}$ in the western side. This area is characterized by the deltaic deposits of alluvial sand and clay. The geology and hydrogeology of this region are reported by Natarajan (1982), CGWB (1991), Sankaran and Natarajan (1980), Varadaraj and Natarajan (1988) and CGWB (1993). This region comprises of various geological formations ranging from the Archaean to recent alluvium. The geological succession of the study region is given in Table 1 . The thickness of Miocene formation ranges from less than $1 \mathrm{~m}$ in the west to more than $600 \mathrm{~m}$ in the east. On the basis of faunal evidence, this formation is further divided into two units: lower Miocene and middle and upper Miocene. The Eocene formation is encountered in boreholes at a depth of about $130 \mathrm{~m}$ in the west and $430 \mathrm{~m}$ in the central and eastern parts of the region (Sukhija et al. 1996).

The Pliocene deposits vary in thickness from $50 \mathrm{~m}$ from west to $75 \mathrm{~m}$ along the coast. The Pliocene deposits are called the Podukkudi formation in the Thanjavur district (UNDP 1971), and the Karaikal beds in the Karaikal area (CGWB 1993). Quaternary formations, which are fluvial and semi-marine in origin are present along the coast and also occupy most of the study area with thickness varying from about $1 \mathrm{~m}$ to $50 \mathrm{~m}$ from west to east, whereas in Karaikal region the Quaternary deposits is of 26-43 m thickness occupying the entire area. This overlies the 


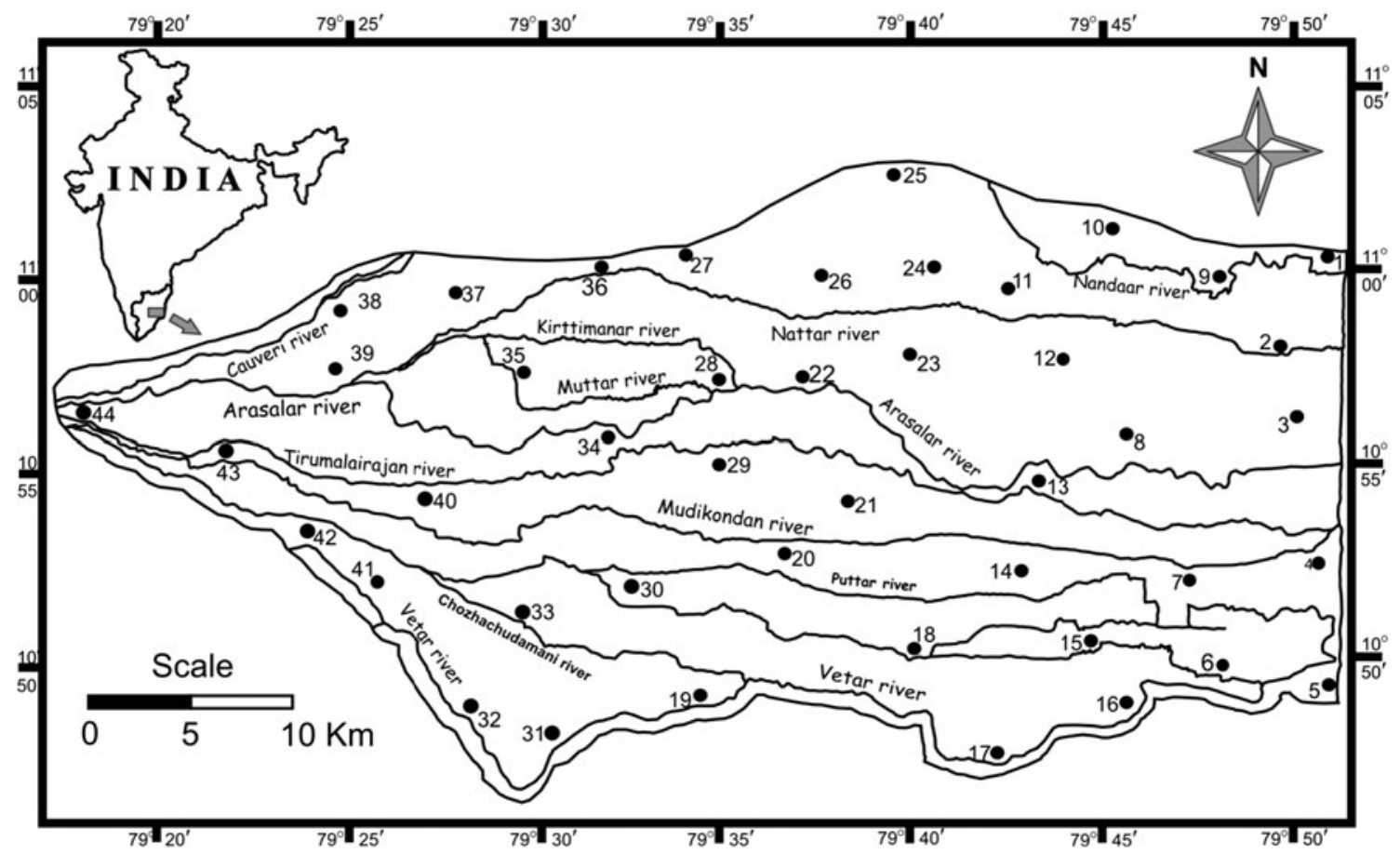

Fig. 1 Location of study area and monitoring wells

Table 1 The geological succession in Cauvery deltaic region

\begin{tabular}{|c|c|c|c|}
\hline Period & Epoch & Formation & Lithology \\
\hline Quaternary & Recent & $\begin{array}{r}\text { Alluvium } \\
\text { laterites }\end{array}$ & $\begin{array}{l}\text { Soils, coastal and river } \\
\text { sands, and laterites }\end{array}$ \\
\hline \multirow[t]{3}{*}{ Tertiary } & Pliocene & Podakkudi & $\begin{array}{l}\text { Sands, clays and minor } \\
\text { limestone }\end{array}$ \\
\hline & Miocene & Cuddalore & $\begin{array}{l}\text { Sands, sandstones, } \\
\text { gravels, with clay and } \\
\text { limestone }\end{array}$ \\
\hline & Eocene & - & Sands, silts and clays \\
\hline \multicolumn{4}{|c|}{...Unconformity... } \\
\hline Mesozoic & Cretaceous & Kuppakkudi & $\begin{array}{l}\text { Calcareous, sandstones, } \\
\text { clays, marls and } \\
\text { siltstones }\end{array}$ \\
\hline \multicolumn{4}{|c|}{...Unconformity... } \\
\hline Precambrian & Archaean & $\begin{array}{l}\text { Eastern } \\
\text { ghat } \\
\text { complex }\end{array}$ & $\begin{array}{c}\text { Gneissic complex and } \\
\text { hornblende granites }\end{array}$ \\
\hline
\end{tabular}

Karaikal beds of Pliocene (50-77 $\mathrm{m}$ ) and Cuddalore formation of Miocene period (about $600 \mathrm{~m}$ ) (Sukhija et al. 1996).

Groundwater occurs in almost all the geological formations of this region. Figure 2 shows the borehole lithology of the study region. In alluvial deposits, groundwater occurs under water-table, in semi confined and confined conditions. Owing to the marine origin of the Karaikal beds, the groundwater is saline and not suitable for domestic or irrigational purposes. Therefore, groundwater development in this formation is limited.

\section{Materials and methods}

Initially well inventory survey was performed and electrical conductivity (EC) of groundwater samples was measured in most of the wells located in this region. After this survey, 44 representative wells were selected for groundwater sampling in May 2010 (Fig. 1). Most of these wells are shallow in nature and have been used for agricultural purpose. EC and $\mathrm{pH}$ were measured in situ using digital meters. The samples were collected in 1-L high-density cleaned polythene containers and rinsed 3-4 times before sampling using the water to be sampled. Collected samples were stored at $4{ }^{\circ} \mathrm{C}$ and transported to the laboratory on the same day. Samples for analysis were filtered through $0.45 \mu \mathrm{m}$ cellulose membranes before analysis.

Collected samples were analysed for major and minor ions using standard methods (APHA-AWWA-WEF 1998). Except alkalinity, all the parameters were analysed using a ion chromatograph (Metrohm 861 Advanced Compact IC). Alkalinity as bicarbonate was determined by titration technique. Overall, measurement reproducibility and precision for each analysis were less than $2 \%$. The analytical precision for the total measurements of ions was checked again by calculating the ionic balance errors and was generally within $\pm 5 \%$. 

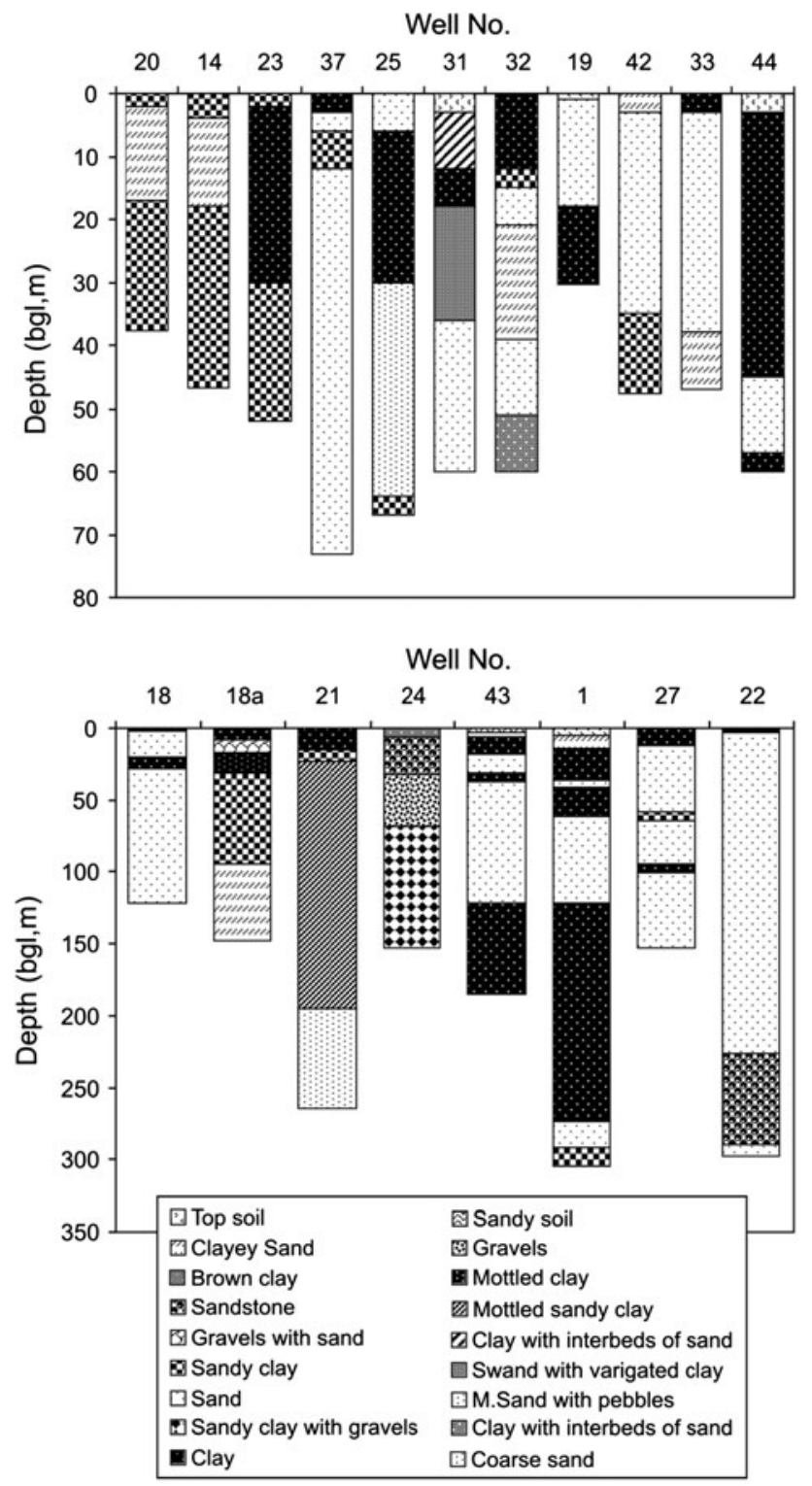

Fig. 2 Borehole lithologs of selected wells in the study area

\section{Results and discussion}

The statistical summary of water chemistry in the study region is given in Table 2 . The $\mathrm{pH}$ of groundwater of the study region varies from 6.6 to 8.1 with an average of 7.1 which indicates that the dissolved carbonates are predominantly in bicarbonate form (Adams et al. 2001). The EC ranges from 500 to $5,500 \mu \mathrm{S} / \mathrm{cm}$ with a mean value of $1,702 \mu \mathrm{S} / \mathrm{cm}$. The total dissolved solids (TDS) calculated from $\mathrm{EC}(\mathrm{TDS}=\mathrm{EC} \times 0.64)$, are between 320 and $3,520 \mathrm{mg} / \mathrm{L}$ with an average of $1,089 \mathrm{mg} / \mathrm{L}$. According to TDS classification (Freeze and Cherry 1979), $39 \%$ of wells come under brackish type (TDS $>1,000 \mathrm{mg} / \mathrm{L}$ ), whereas $61 \%$ belong to fresh water category (TDS $<1,000 \mathrm{mg} / \mathrm{L}$ ). Chloride concentration of groundwater ranges between 56
Table 2 Statistical summary of chemical parameters

\begin{tabular}{lllll}
\hline Parameter & Min & Max & Mean & Median \\
\hline $\mathrm{pH}$ & 6.6 & 8.1 & 7.1 & 7 \\
$\mathrm{EC}$ & 500 & 5,500 & 1,702 & 1,200 \\
$\mathrm{TDS}$ & 320 & 3,520 & 1,089 & 768 \\
$\mathrm{TH}$ & 15 & 878 & 339 & 278 \\
$\mathrm{Na}$ & 23 & 853 & 233 & 127 \\
$\mathrm{~K}$ & $\mathrm{BDL}$ & 189 & 26.8 & 6.52 \\
$\mathrm{Ca}$ & 2.46 & 268 & 83.6 & 73 \\
$\mathrm{Mg}$ & 1.7 & 107 & 31.8 & 27.6 \\
$\mathrm{Alkalinity}$ & 98 & 841 & 353 & 323 \\
$\mathrm{Cl}$ & 56 & 1,435 & 302 & 173 \\
$\mathrm{SO}_{4}$ & 14 & 247 & 81.7 & 75 \\
$\mathrm{NO}_{3}$ & BDL & 120 & 31 & 19.9 \\
$\mathrm{NH}_{4}$ & 0.02 & 49.6 & 3.6 & 0.6 \\
$\mathrm{NO}_{2}$ & BDL & 7.02 & 0.2 & 0.02 \\
$\mathrm{~F}$ & 0.01 & 1.5 & 0.3 & 0.27 \\
$\mathrm{Br}$ & BDL & 4.12 & 0.6 & 0.31 \\
$\mathrm{PO}_{4}$ & BDL & 6.12 & 0.9 & 0.27 \\
\hline $\mathrm{Units}$ & $\mathrm{m} / \mathrm{L}$ & &
\end{tabular}

Units $=\mathrm{mg} / \mathrm{L}$, except EC $(\mu \mathrm{S} / \mathrm{cm})$ and $\mathrm{pH}$

and $1,435 \mathrm{mg} / \mathrm{L}$ with a mean value of $302 \mathrm{mg} / \mathrm{L}$. Chloride concentration in the samples were generally less than $500 \mathrm{mg} / \mathrm{L}$ except for five wells.

Spatial variation in groundwater chemistry

Spatial variation of selected ions in the study region is shown in Fig. 3. EC, ammonium, phosphate and chloride contents are high in groundwater of the coastal region. A few wells located in the central and northern region have high concentration of nitrate. Potassium concentration in water samples collected from wells in coastal region and in some wells away from the coastal region is high. Major ions such as sodium, calcium, magnesium, sulphate and bicarbonate did not show any particular spatial trend. Generally, bromide is a good indicator of influence of saline sources (Andreasen and Fleck 1997). The concentration of bromide in the wells located near the coast is generally greater than $1 \mathrm{mg} / \mathrm{L}$ indicating the influence of seawater mixing. In contrast, fluoride concentration is high in central and northern parts, whereas it is low in the coastal region (Fig. 3).

High EC and chloride concentrations in the eastern part explain that the groundwater quality is largely influenced by saline sources (saline water intrusion and sea spray). Higher values of EC associated with the wells away from coastal region probably indicate a longer residence time, surface contamination and evaporation enriched irrigation return flow. Spatial distribution of nitrate, ammonium and phosphate imply that groundwater quality is affected by surface sources of contamination. Spatial variation of 


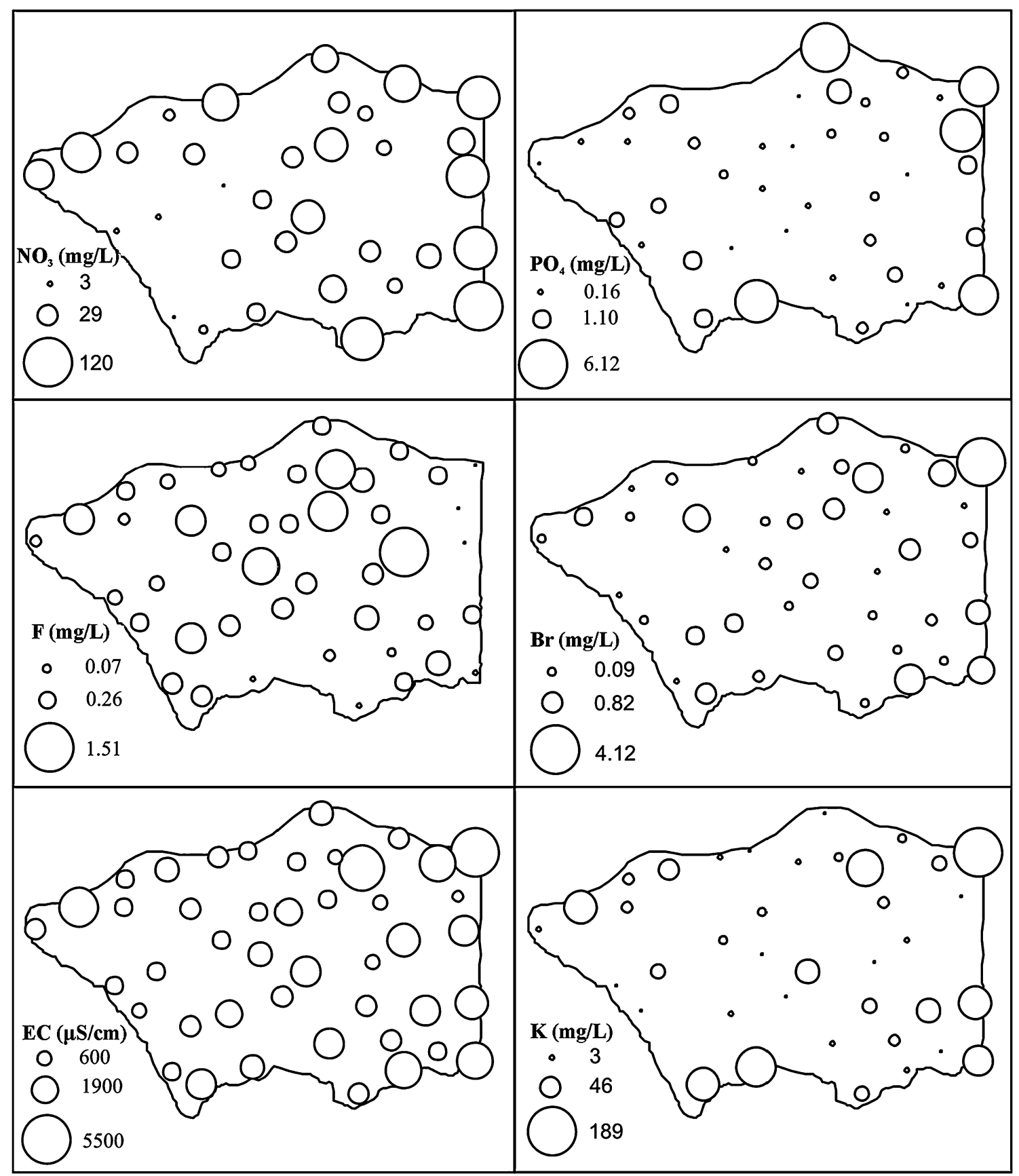

Fig. 3 Spatial variation of selected parameters in the study region

fluoride indicates that it would have been derived by soilwater interaction and not from the sea. Hence, the groundwater quality in the study region is likely to be controlled saline sources, surface contamination and soilwater interaction.

\section{Vertical variation in groundwater chemistry}

It is well known that vertical variation in concentration of ions will give better idea about the surface contamination.
Figure 4 illustrates the vertical variation of major and minor ions in the study region derived based on the depth of the well. Except pH, alkalinity and fluoride, all the ions follow a similar trend. Shallow wells have high concentrations of ions compared with deep wells. This suggests that the groundwater quality is affected by surface sources of contamination resulting due to agricultural activities (fertilizers, farm manure and irrigation return flow) and domestic wastewaters (sewage waters, wastewater canals near the wells, etc.). Geologically there is no known source 
Fig. 4 Vertical variation in EC, major and minor ions in groundwater
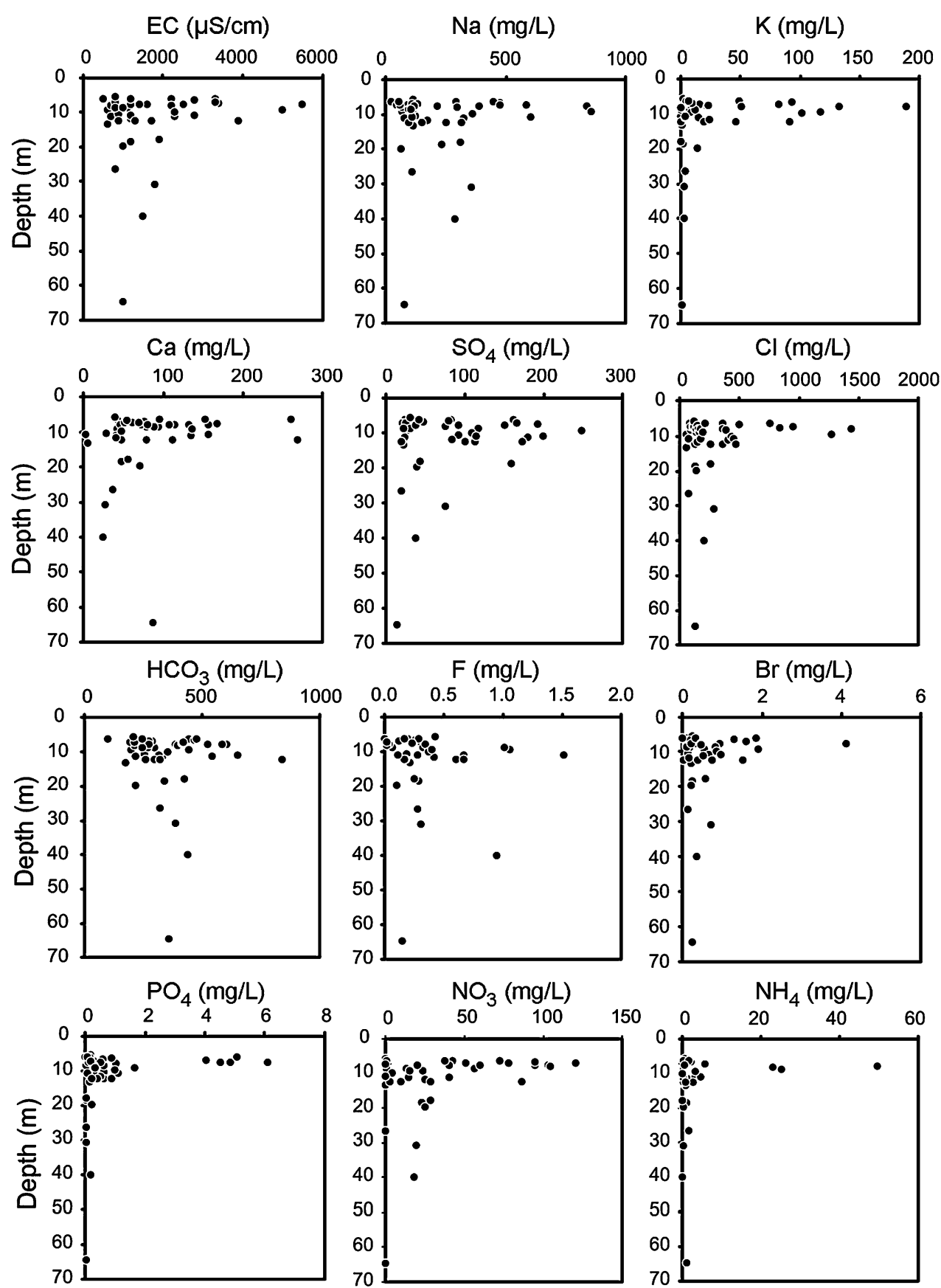

of chloride and nitrate in the formations of this area. It is understandable that high concentrations of nitrate, ammonium and phosphate reveal the influence of surface source of contamination since the wells located in the coastal region are also shallow, whereas high concentrations of sodium, magnesium, sulphate and chloride in these wells reveal the influence of saline sources.

Vertical variation of $\mathrm{pH}$ and alkalinity indicates that there is no significant variation with respect to depth. Figure 4 displays that relatively high fluoride was also found in shallow wells. Earlier researchers reported that fluoride is mostly originated from the geogenic sources and processes (Apambire et al. 1997; Ayoob and Gupta 2006; Edmunds and Smedley 2005; Reddy and Prasad 2003). In the study region, fluoride seems to be derived from surface contamination sources and/or aquifer minerals, which is discussed in the later sections.

Groundwater contamination sources and processes

Spatial and vertical variations in water chemistry elucidate that groundwater chemistry is not homogenous and 
affected by saline sources and surface contaminants in the study region. Piper diagram (Fig. 5) illustrates that most of the samples are $\mathrm{Na}-\mathrm{Cl}$ type $(45 \%)$ followed by mixed $\mathrm{Ca}-\mathrm{Mg}-\mathrm{Cl}(27 \%)$ type. The dominant water types are in the order of $\mathrm{Na}-\mathrm{Cl}>$ mixed $\mathrm{Ca}-\mathrm{Mg}-\mathrm{Cl}>$ mixed $\mathrm{Ca}-\mathrm{Na}-$ $\mathrm{HCO}_{3}>\mathrm{Ca}-\mathrm{HCO}_{3}>\mathrm{Na}-\mathrm{HCO}_{3}$.

Influences of saline sources on water chemistry

EC of groundwater in this area is less than $2,000 \mu \mathrm{S} / \mathrm{cm}$ in $71 \%$ of wells in the study region. But, wells located near the coast have groundwater with high EC values $(\mathrm{EC}>2,000 \mu \mathrm{S} / \mathrm{cm})$. Groundwater in the coastal wells is enriched in sodium, potassium, magnesium, chloride, bromide and sulphate. EC has strong correlation with chloride $\left(R^{2}=0.9\right)$, sodium $\left(R^{2}=0.88\right)$, bromide $\left(R^{2}=0.7\right)$ and sulphate $\left(R^{2}=0.6\right)$ (Fig. 6). Likewise, chloride also has strong correlation with sodium $\left(R^{2}=0.9\right)$ and bromide $\left(R^{2}=0.8\right)$ (Fig. 6). Bromide is a good indicator for saline water intrusion and coastal wells have high bromide content. Further, bromide has significant correlation with EC, sodium, chloride and sulphate (Fig. 6). These observations demonstrate that the water chemistry in the study region is affected by saline water intrusion and/or sea spray.

Role of surface contamination sources on water chemistry

Groundwater in the study region is highly contaminated by surface contamination sources. Saline sources affected the water quality only in the coastal region whereas surface contaminants influenced the water quality both in coastal as well as interior wells. Aquaculture activities in the

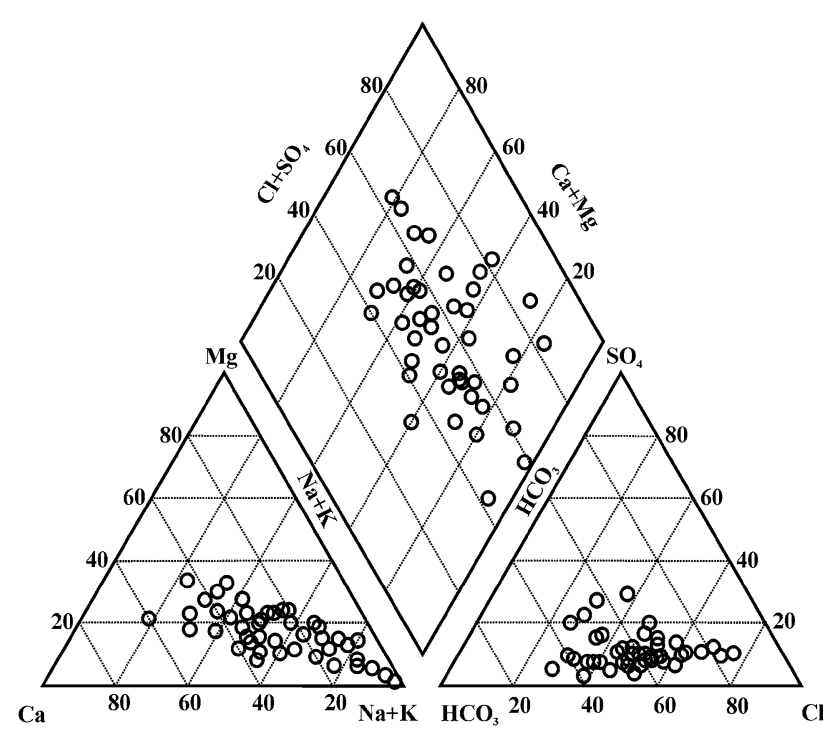

Fig. 5 Groundwater type in the study area agricultural lands near the coast enhanced the contaminant load in groundwater, especially of nitrate, nitrite, ammonium and phosphate. Spatial variation pattern of these parameters explain this observation (Fig. 3). Improper disposal of wastes and sewage near the drinking water wells also affected the groundwater quality. Especially wells 3, 4, 5, 21 and 23 explain the impact of domestic wastewater where canal carrying sewage and sewage pits near these wells were observed during field visits. Further, detergents in the wastewater may enhance concentrations of sodium, potassium and chloride in the groundwater (Jiang et al. 2009). Potassium distribution evidently suggests the impact of surface contamination sources. Potassium in groundwater of coastal part would have been derived due to seawater mixing, whereas the high potassium in inland region may be due to sources of surface contamination. Irrigation return flow and application of synthetic fertilizers and farm manures have strong influences on groundwater quality in the study region. Wells 17 , $18,25,36,44$ and 45 have high nitrate content and express influences of agricultural activities because these wells are surrounded by mostly agricultural lands. In the study area, urea $\left(\mathrm{CO}\left(\mathrm{NH}_{2}\right)_{2}\right)$, ammonium sulfate $\left(\left(\mathrm{NH}_{4}\right)_{2} \mathrm{SO}_{4}\right), \mathrm{N}: \mathrm{P}: \mathrm{K}$ and potash $(\mathrm{KCl})$ are the commonly used fertiliser in the paddy field. However, there is no significant correlation between nitrate, sulphate and potassium which explains that these ions would be effectively held in the soils by organic matter and clays. According to Bohlke (2002), the origin of potassium from $\mathrm{KCl}$ fertilizer applications is complicated due to ion exchange reactions.

\section{Soil-water interaction}

Interaction between groundwater and aquifer materials is common in all aquifers. However, anthropogenic activities dominate the natural process and degrade the water quality. In the present study, most of the ions are derived from saline and surface contamination sources. However, fluoride shows different trend and highlights the role of soilwater interaction. Fluoride has negative correlation with chloride, bromide and nitrate (Fig. 7). These observations ruled out the relation between fluoride, saline and surface contamination sources.

Speciation calculations were carried out for carbonate, sulphate and fluoride minerals using PHREEQC (Parkhurst and Appelo 1999) for selected minerals. The results manifest that groundwater of the study site is saturated and supersaturated with respect to carbonate minerals and undersaturated with respect to fluorite and gypsum. Fluoride occurs in a combined form in rocks and soil in wide variety minerals such as fluorspar (fluorite), cryolite, apatite, topaz and their corresponding host rocks such as granite, basalt, syenite, and shale (Apambire et al. 1997; 

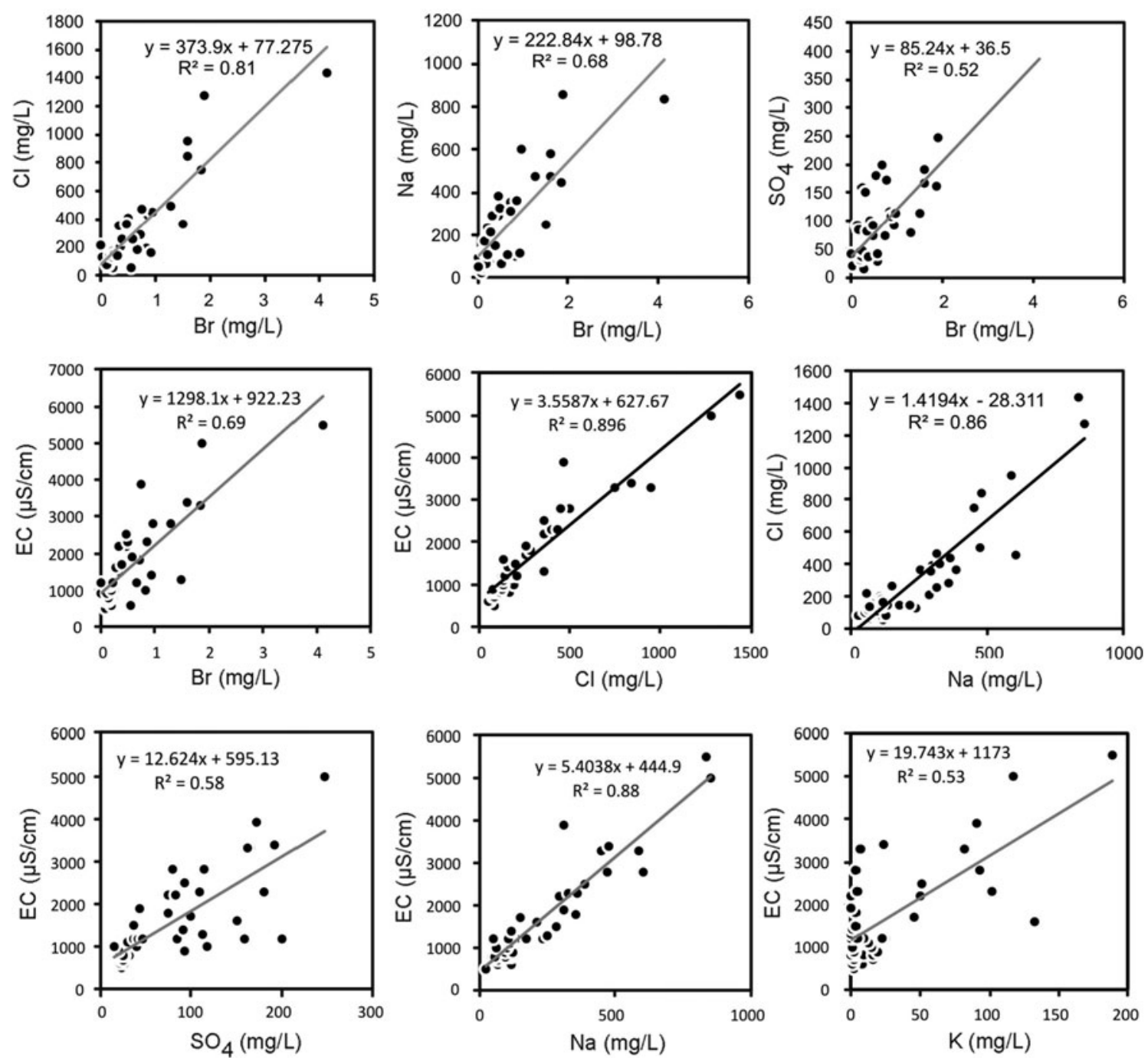

Fig. 6 Correlation between various parameters of groundwater

Ayoob and Gupta 2006; Buxton and Shernoff 1999; Edmunds and Smedley 2005; Hamilton et al. 1982; Reddy and Prasad 2003; WHO 1994). According to Jacks et al. (2005), fluoride is originated by condensation of soluble components due to evaporation and evapotranspiration. However, the absence of significant correlation between chloride and fluoride rules out this mechanism. Further, usage of phosphatic fertilizers in the paddy field seems to be one of the sources for fluoride (Saxena and Ahmed 2003). The use of phosphate fertilizers in this region might also be the reason for increased concentration fluoride as these fertilizers have fluoride concentration of $13.77 \mathrm{mg} / \mathrm{kg}$ (Brindha 2012). But, fluoride concentration in groundwater is does not correlate with phosphate concentration. As per the geology, the study region is covered by deltaic deposits of alluvial sands and clays (black and brown colour). Borehole lithology (Fig. 2) indicates that clay and clayey sands are dominated in the study area and occur mostly as top layers followed by sand formation. Figure 4 displays that high fluoride was observed in the shallow wells. These observations suggest that clay-water interaction seems to be a major source of fluoride in the study region followed by the use of phosphate fertilizers.

Groundwater quality assessment

\section{Domestic water quality}

As mentioned earlier, the groundwater is a sole source for domestic and irrigational activities in the study region. In order to assess the groundwater suitability for these purposes, various quality standards were employed. World Health Organisation (WHO 1993) and Indian Bureau of Indian Standards (BIS 2003) were compared with analytical results. TDS is one of the important parameter to assess the water quality. According to WHO standards, 
Fig. 7 Relation between $\mathrm{Br}, \mathrm{Cl}$, $\mathrm{NO}_{3}, \mathrm{EC}$ and $\mathrm{F}$ in the study area
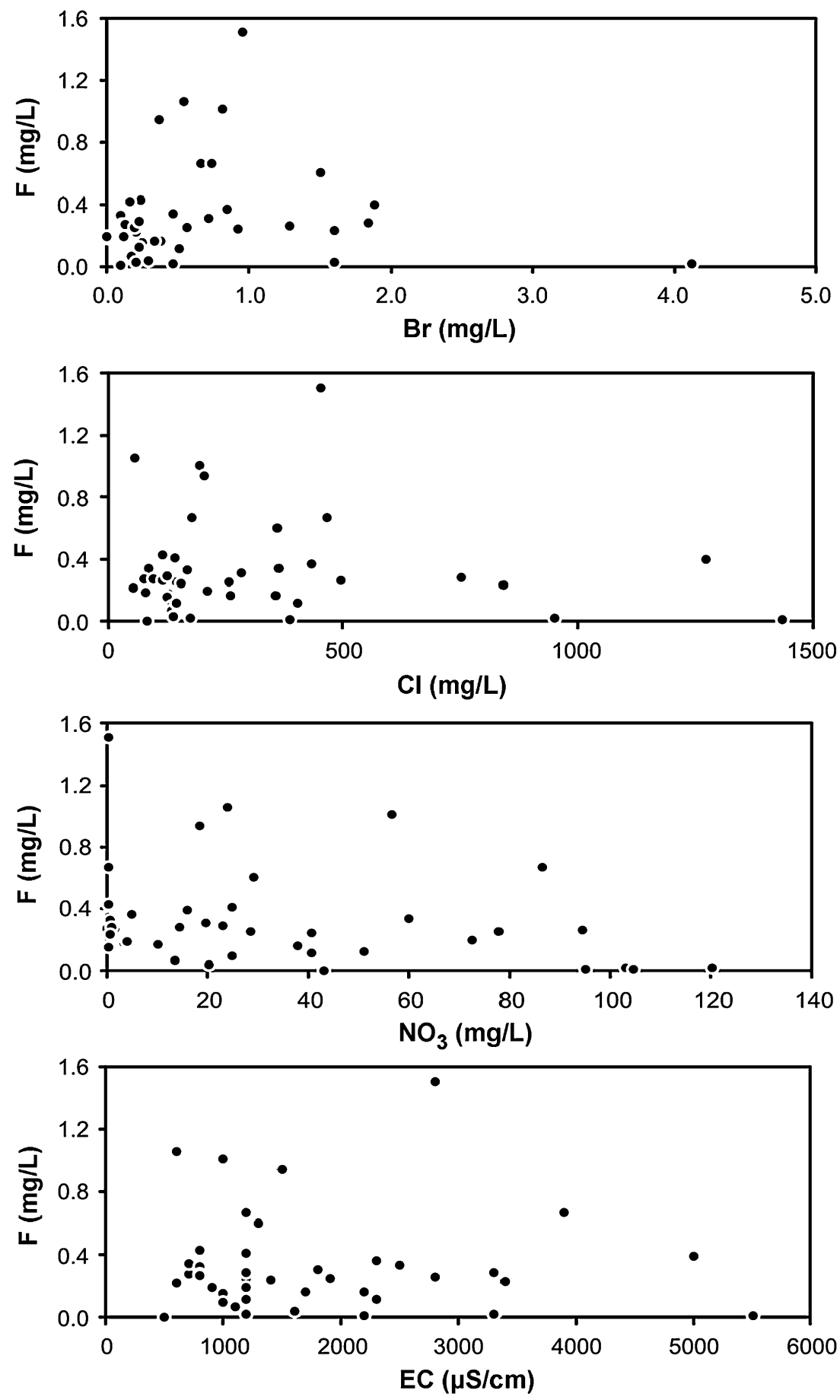

$21 \%$ of samples are not fit for drinking due to TDS which exceeds 1,500 mg/L (Table 3). Davies and DeWiest (1966) have classified the groundwater samples using TDS. Based on this classification (Table 4), $11 \%$ of samples are desirable for drinking while $50 \%$ of samples are permissible for drinking purposes in the study area. Besides, total hardness (TH) is an essential criterion to determine the water quality for drinking, domestic and industrial activities. TH of groundwater of the study area varies between 15 and $878 \mathrm{mg} / \mathrm{L}$ with an average value of $339 \mathrm{mg} / \mathrm{L}$. Table 3 indicates that $18 \%$ of samples exceed WHO standards ( $\mathrm{TH}>500)$, whereas $11 \%$ of samples exceed Indian standards $(\mathrm{TH}>600)$ based on $\mathrm{TH}$. According to classification based on total hardness (Table 5), $90 \%$ of samples belong to hard to very hard category. Hard water causes unpleasant taste, scale formations in pipes and on plumping fixtures and reduces lather-forming ability of soap. Potassium was greater than the prescribed limit of $12 \mathrm{mg} / \mathrm{L}$ 
Table 3 Groundwater quality evaluation using WHO and BIS for drinking purposes

\begin{tabular}{llllll}
\hline $\begin{array}{l}\text { Water quality } \\
\text { parameters }\end{array}$ & \multicolumn{2}{l}{$\begin{array}{l}\text { Max permissible } \\
\text { limit }\end{array}$} & & \multicolumn{2}{l}{$\begin{array}{l}\text { Percentage exceeding the limit } \\
\text { for drinking water }\end{array}$} \\
\cline { 2 - 3 } & $\begin{array}{l}\text { WHO } \\
(1993)\end{array}$ & $\begin{array}{l}\text { BIS } \\
(2003)\end{array}$ & & $\begin{array}{l}\text { According to } \\
\text { WHO (1993) }\end{array}$ & $\begin{array}{l}\text { According to } \\
\text { (BIS 2003) }\end{array}$ \\
\hline $\mathrm{pH}$ & 8.5 & $6.5-9.5$ & - & - \\
$\mathrm{TDS}(\mathrm{mg} / \mathrm{L})$ & 1,500 & 2,000 & 21 & 14 \\
$\mathrm{TH}(\mathrm{as} \mathrm{CaCO})$ & 500 & 600 & 18 & 11 \\
$(\mathrm{mg} / \mathrm{L})$ & & & & 5 \\
$\mathrm{Ca}^{2+}(\mathrm{mg} / \mathrm{L})$ & 200 & 200 & 5 & 2 \\
$\mathrm{Mg}^{2+}(\mathrm{mg} / \mathrm{L})$ & 150 & 100 & - & 43 \\
$\mathrm{Na}^{+}(\mathrm{mg} / \mathrm{L})$ & 200 & 200 & 43 & - \\
$\mathrm{K}^{+}(\mathrm{mg} / \mathrm{L})$ & 12 & - & 39 & 25 \\
$\mathrm{NO}_{3}{ }^{-}(\mathrm{mg} / \mathrm{L})$ & - & 45 & 25 & 5 \\
$\mathrm{Cl}^{-}(\mathrm{mg} / \mathrm{L})$ & 600 & 1,000 & 11 & - \\
$\mathrm{SO}_{4}{ }^{2-}(\mathrm{mg} / \mathrm{L})$ & 400 & 400 & - & - \\
$\mathrm{F}^{-}(\mathrm{mg} / \mathrm{L})$ & 1.5 & & - & 43 \\
\hline
\end{tabular}

Table 4 Classification of groundwater based on TDS

\begin{tabular}{lll}
\hline TDS & Water type & Percentage \\
\hline Up to 500 & Desirable for drinking & 11.1 \\
$500-1,000$ & Permissible for drinking & 50 \\
$<3,000$ & Useful for irrigation & 34.1 \\
$>3,000$ & Unfit for drinking and irrigation & 4.5 \\
\hline
\end{tabular}

Table 5 Classification of the groundwater based on Total Hardness

\begin{tabular}{llc}
\hline $\begin{array}{l}\text { Total hardness } \\
\left.\text { as } \mathrm{CaCO}_{3}, \mathrm{mg} / \mathrm{L}\right)\end{array}$ & $\begin{array}{l}\text { Water } \\
\text { classification }\end{array}$ & $\begin{array}{l}\text { Percentage } \\
\text { of wells }\end{array}$ \\
\hline$<75$ & Soft & 5 \\
$75-150$ & Moderately hard & 5 \\
$150-300$ & Hard & 47 \\
$>300$ & Very hard & 43 \\
\hline
\end{tabular}

(WHO 1993) in $39 \%$ of the groundwater samples. Potassium is an essential element in humans; however, increased exposure to potassium could result in significant health effects in people with kidney disease or other conditions, such as heart disease, coronary artery disease, hypertension, diabetes, adrenal insufficiency and pre-existing hyperkalaemia (WHO 2009). Besides, chloride and nitrate are important constituents that decide the suitability of groundwater for drinking. Based on chloride, $11 \%$ of samples exceed the allowable limit prescribed by WHO. The concentration of nitrate ranges from below detection limit (BDL) to $120 \mathrm{mg} / \mathrm{L}$ with an average value of $31 \mathrm{mg} /$ L. In the study region, $25 \%$ of wells are not fit for drinking

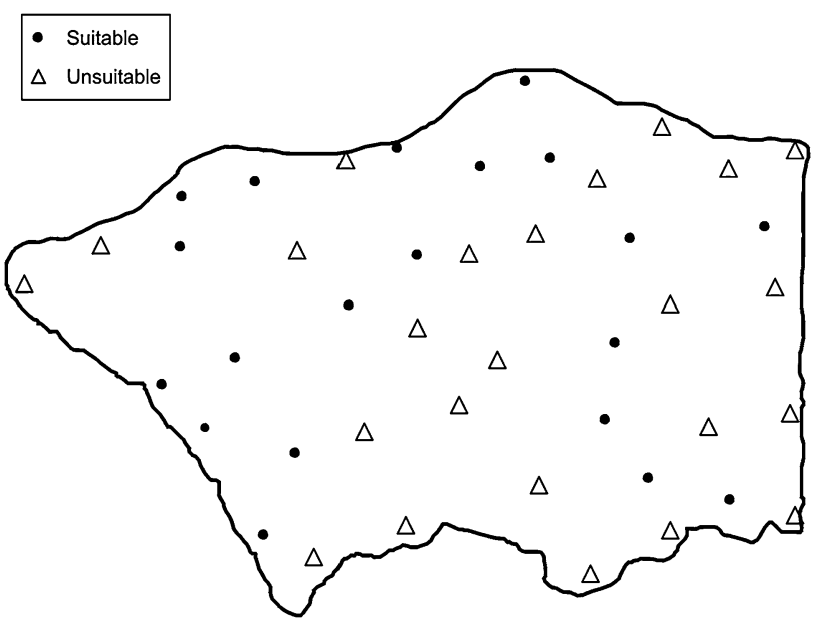

Fig. 8 Integrated suitability map for drinking in the study region

Table 6 Classification of the groundwater quality according to the USDA method

\begin{tabular}{llllll}
\hline $\begin{array}{l}\text { Sodium } \\
\text { hazard }\end{array}$ & \multicolumn{2}{l}{ Salinity hazard } & & & \\
\cline { 2 - 6 } & Low & Medium & High & Very high & Very very high \\
C1 & C2 & C3 & C4 & C5 \\
\hline Low & & & & & \\
S1 & - & $6.8 \%$ & $54.6 \%$ & - & - \\
Medium & & & & & \\
S2 & - & $2.3 \%$ & $13.6 \%$ & $11.4 \%$ & - \\
High & & & & & \\
S3 - & - & - & $4.5 \%$ & - \\
Very high & & & & \\
S4 & - & - & - & $4.5 \%$ & $2.3 \%$ \\
\hline
\end{tabular}

due to high nitrate concentration (nitrate $>45 \mathrm{mg} / \mathrm{L}$ ) (Table 3). High concentration of nitrate in the drinking water is toxic and causes methemoglobinemia/blue baby disease and gastric carcinomas in infants, leading to their death. As far as fluoride is concerned, all of the groundwater samples are within the maximum recommended limit $(1.5 \mathrm{mg} / \mathrm{L})$ prescribed by WHO.

In order to predict the groundwater wells suitable for drinking in the study site, integrated suitability map was created using all the standards, recommended by both WHO (2009) and BIS (2003). The map is prepared based on the concept that if the water sample exceeds any one of the standards (Table 3), the well is not fit for drinking. Figure 8 shows the integrated suitability map for drinking. Of the 44 sampling wells, 24 wells $(55 \%)$ are not suitable for drinking and exceed any one of the quality parameters recommended by WHO and BIS. 


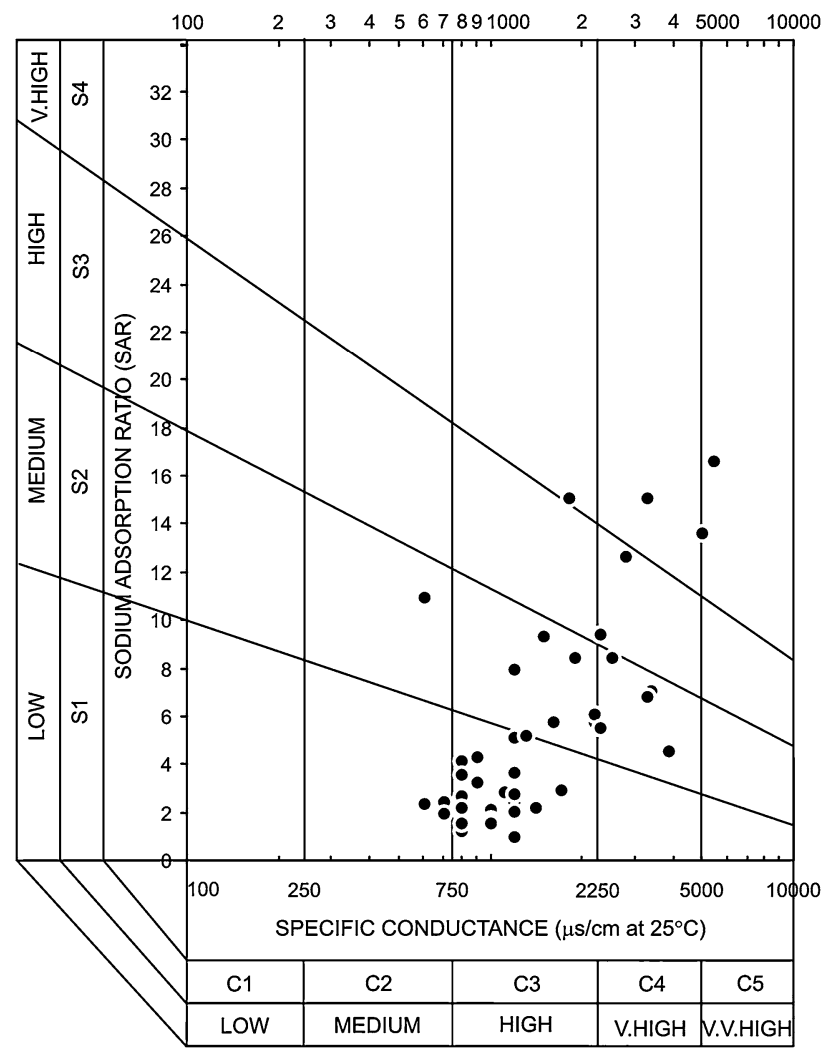

Fig. 9 USSL classification of groundwater in the study area

\section{Agricultural water quality}

Livelihood of people in this area depends on agricultural activities. Since rivers are non-perennial in nature and also due to frequent failure of monsoons, surface water availability for irrigation is limited. Hence, irrigation requirement mainly depends on groundwater. The groundwater quality for irrigation was evaluated using EC, SAR, USSL classification, Food and Agricultural Organization (FAO) and RSC. EC is a good measure of salinity hazard to crops. Based on EC, irrigation water is classified into four groups such as low $(<250 \mu \mathrm{S} / \mathrm{cm})$, medium $(250-750 \mu \mathrm{S} / \mathrm{cm})$, high (750-2,250 $\mu \mathrm{S} / \mathrm{cm})$ and very high $(2,250-5,000$ $\mu \mathrm{S} / \mathrm{cm}$ ) salinity (Richards 1954). High-salinity water increases soil water salinity by evaporation, which will greatly reduce plant water uptake through osmotic effect and causes dehydration and low yield. In the study area, $74 \%$ of samples are classified into medium to high salinity water (Table 6). Excess sodium in the irrigation water enhances the exchange of sodium in the soil and affects soil permeability and texture. Sodium hazard in the irrigation water was estimated by SAR using the following relation: $\mathrm{SAR}=\mathrm{Na} /[(\mathrm{Ca}+\mathrm{Mg}) / 2]^{0.5}$, units are expressed in meq/L

According to SAR classification, 61 and $27 \%$ of samples come under low and medium sodium water,

Table 7 Classification of groundwater quality for irrigation

\begin{tabular}{|c|c|c|c|c|c|c|}
\hline \multirow[t]{2}{*}{ Potential irrigation problem } & \multicolumn{3}{|c|}{ Degree of restriction on use } & \multicolumn{3}{|c|}{ No. of samples $(\%)$} \\
\hline & None & Slight to moderate & Severe & None & Slight to moderate & Severe \\
\hline \multicolumn{7}{|l|}{ Salinity (affects crop water availability) } \\
\hline $\mathrm{EC}(\mu \mathrm{S} / \mathrm{cm})$ & $<700$ & $700-3000$ & $>3,000$ & $7 \%$ & $79 \%$ & $14 \%$ \\
\hline \multicolumn{7}{|c|}{ Infiltration (affects infiltration rate of water into the soil. Evaluate using EC and SAR together) } \\
\hline \multicolumn{7}{|l|}{$\mathrm{EC}(\mu \mathrm{S} / \mathrm{cm})$} \\
\hline \multicolumn{7}{|l|}{ SAR } \\
\hline $0-3$ & $>700$ & $700-200$ & $<200$ & $36 \%$ & $5 \%$ & Nil \\
\hline $3-6$ & $>1,200$ & $1,200-300$ & $<300$ & $11 \%$ & $14 \%$ & Nil \\
\hline $6-12$ & $>1,900$ & $1,900-500$ & $<500$ & $11 \%$ & $9 \%$ & Nil \\
\hline $12-20$ & $>2,900$ & $2,900-1,300$ & $<1,300$ & $7 \%$ & $5 \%$ & Nil \\
\hline $20-40$ & $>5,000$ & $5,000-2,900$ & $<2,900$ & Nil & Nil & $2 \%$ \\
\hline \multicolumn{7}{|l|}{ Specific ion toxicity (affects sensitive crops) } \\
\hline \multicolumn{7}{|l|}{ Sodium (SAR) } \\
\hline Surface irrigation & $<3$ & $3-9$ & $>9$ & $41 \%$ & $39 \%$ & $20 \%$ \\
\hline Sprinkler irrigation & $<3$ & $>3$ & & $41 \%$ & $59 \%$ & Nil \\
\hline \multicolumn{7}{|l|}{ Chloride (meq/L) } \\
\hline Surface irrigation & $<4$ & $4-10$ & $>10$ & $39 \%$ & $29 \%$ & $32 \%$ \\
\hline Sprinkler irrigation & $<3$ & $>3$ & & $18 \%$ & $82 \%$ & \\
\hline \multicolumn{7}{|l|}{ Miscellaneous effects (affects susceptible crops) } \\
\hline Nitrate nitrogen $(\mathrm{mg} / \mathrm{L})$ & $<5$ & $5-30$ & $>30$ & $52 \%$ & $48 \%$ & Nil \\
\hline Bicarbonate (overhead sprinkling only) (meq/L) & $<1.5$ & $1.5-8.5$ & $>8.5$ & Nil & $86 \%$ & $14 \%$ \\
\hline
\end{tabular}


respectively, in the study site (Table 6). Detailed assessment was carried out using USSL classification (Fig. 9) where EC and SAR were employed together (United States Salinity Laboratory 1954). Figure 9 illustrates that most of the samples were plotted on C3S1 $(54.6 \%)$ and C3S2 (13.6\%) category. Water samples that plot in the zone of C3S1 can be used for irrigation on most of the soil types with little caution about exchangeable sodium. Samples falling in C3S2 category are not suitable for irrigation purposes.

The suitability of water for agricultural purposes is also evaluated using FAO classification (Ayers and Westcot 1994) (Table 7). In this classification, EC, SAR, sodium, chloride, nitrate and bicarbonate were employed. Based on EC, $79 \%$ of samples come under slight to moderate category for agricultural use, whereas $14 \%$ have severe salinity restrictions (Table 7). Generally, $84 \%$ of samples in the study region are low sodium water (SAR $<10)$, and are applicable for all crops and soil condition. In the FAO system also, SAR and EC are used together to understand the effect on water infiltration rate, which will be increased with increasing EC at a given SAR (Table 7). As per the chloride toxicity, there is no restriction for $18 \%$ of samples while $82 \%$ of samples have slight to moderate restrictions to apply in sprinkler irrigation. For surface irrigation, $68 \%$ of samples have none and slight to moderate restrictions to use. Besides, RSC was also calculated to assess the suitability of water for irrigation using the following equation (Eaton 1950):

$$
\begin{aligned}
\mathrm{RSC}= & \left(\mathrm{CO}_{3}^{-}+\mathrm{HCO}_{3}\right)-\left(\mathrm{Ca}^{++}\right. \\
& \left.+\mathrm{Mg}^{++}\right), \text {units are expressed in meq } / \mathrm{L}
\end{aligned}
$$

Suitability of water for irrigation was classified into three groups: suitable $(<1.25)$, marginal $(1.25-2.5)$ and not suitable $(>2.5)$, using RSC. In the study area, $77 \%$ of samples are suitable for irrigation $(\mathrm{RSC}<1.25)$ and $14 \%$ of samples are marginal and the remaining is not suitable for irrigation.

\section{Conclusion}

The present study was carried out to assess the sources of contamination and groundwater quality for domestic and agricultural activities in the deltaic region of Cauvery River, Tamil Nadu, India. In this area water requirements for domestic and agricultural use are largely met by groundwater abstraction because of lack of surface water due to non-perennial nature of Cauvery River and frequent failure of monsoons. Groundwater samples were collected from 44 wells from the study region and analysed for major and minor ions. Results indicate that groundwater quality is influenced by saline and surface sources of contamination such as improper disposal of wastes, sewage/drainage canals near the wells, irrigation return flow and application of synthetic fertilizers and farm manures. Wells in the coastal region are enriched in sodium, potassium, magnesium, chloride, sulphate and bromide which indicate effect of seawater mixing. Spatial and vertical distribution of ions reveals that coastal as well as shallow wells have high EC, chloride, nitrate, ammonium and phosphate. Vertical variations indicate that shallow wells have elevated concentrations of all the ions except alkalinity and fluoride. Fluoride displays negative correlation with chloride, bromide and nitrate which imply that fluoride seems to be derived from aquifer minerals-water interactions followed by phosphate fertilizers. Integrated suitability map for drinking was created based on the concept that if the water sample exceeds any one of the standards (WHO, BIS) the well water is not fit for drinking. The map illustrates that 24 wells (55 \%) are not suitable for drinking. Groundwater quality for agricultural activities was assessed using EC, SAR, RSC, USSL and FAO methods. Based on EC, $74 \%$ of samples are classified into medium to high salinity water. According to FAO method, $84 \%$ of samples are low sodium water and are applicable for all crops and soils. In general, the water quality in the study area is affected by surface contamination sources followed by saline water intrusion in the coastal region. The study concluded that proper management plan is necessary to preserve the groundwater resource in the study region. Further, integrated suitability map prepared in the study will be useful for future groundwater development and planning in the study area.

Acknowledgments The authors would like to thank the Department of Science and Technology (Grant: SR/S4/ES-21/Cauvery/P6) for providing financial assistance for this investigation. They also acknowledge the Department of Science and Technology's Funds for Improvement in Science and Technology scheme (Grant: SR/FST/ ESI-106/2010), University Grants Commission's Special Assistance Programme (Grant: UGC DRS II F.550/10/DRS/2007(SAP-1)) and University Grants Commission's Centre with Potential for Excellence in Environmental Science (Grant: F.No.1-9/2002 NS/PE) for their financial support which helped in creating facilities to carry out this work.

\section{References}

Adams S, Titus R, Pietersen K, Tredoux G, Harris C (2001) Hydrochemical characteristics of aquifers near Sutherland in the Western Karoo, South Africa. J Hydrol 241:91-103

Al-Futaisi A, Rajmohan N, Al-Touqi S (2007) Groundwater quality monitoring in and around Barka dumping site, Sultanate of Oman. In: The Second IASTED (The International Association of Science and Technology for Development) International Conference on Water Resources Management (WRM 2007), Honolulu, Hawaii, USA, 20-22 August 1978

Andreasen DC, Fleck WB (1997) Use of bromide:chloride ratio to differentiate potential sources of chloride in a shallow, 
unconfined aquifer affected by brackish water intrusion. Hydrogeol J 5:17-26

Apambire WB, Boyle DR, Michel FA (1997) Geochemistry, genesis, and health implications of fluoriferous groundwaters in the upper regions of Ghana. Environ Geol 33:13-24

APHA-AWWA-WEF (1998) Standard methods for the examination of water and wastewater. American Public Health Association, Washington, DC

Ayers RS, Westcot DW (1994) Water quality for agriculture, FAO irrigation and drainage paper, 29(1). Food and Agriculture Organization of the United Nation, Rome, pp 1-95

Ayoob S, Gupta AK (2006) Fluoride in drinking waters: a review on the status and stress effects. Crit Rev Environ Sci Technol 36:433-487

Banner JL, Wasserburg GJ, Dobson PF, Carpenter AB, Moore CH (1989) Isotopic and trace element constraints on the origin and evolution of saline groundwaters from central Missouri. Geochim Cosmochim Acta 53:383-398

BIS (2003) Bureau of Indian Standards Specification for drinking water, IS: 10500:91. Revised 2003. Bureau of Indian Standards, New Delhi

Bohlke JK (2002) Groundwater recharge and agricultural contamination. Hydrogeol J 10:153-179

Brindha, K (2012) Assessment of fluoride and uranium in groundwater and hydrogeochemical modelling in a proposed uranium tailings pond area, southern India. Ph.D thesis (Unpublished). Anna University, India, p 143

Brindha K, Elango L (2011) Hydrochemical characteristics of groundwater for domestic and irrigation purposes in Madhuranthakam, Tamil Nadu, India. Earth Sci Res J 15(2):101-108

Brindha K, Rajesh R, Murugan R, Elango L (2011) Fluoride contamination in groundwater in parts of Nalgonda district, Andhra Pradesh, India. Environ Monit Assess 172:481-492

Brink CVD, Frapporti G, Griffioen J, Zaadnoordijk WJ (2007) Statistical analysis of anthropogenic versus geochemical-controlled differences in groundwater composition in the Netherlands. J Hydrol 336:470-480

Buxton HT, Shernoff PK (1999) Groundwater resources of kings and Queens Counties, Long Island, New York. USA Geological Survey Water Supply paper no 2498, New York, USA

CGWB (1991) Groundwater resources and developmental potential of Thanjavur district, Tamil Nadu. CGWB, Hyderabad, pp 1-49

CGWB (1993) Groundwater resources and development prospects in Karaikal region. Union Territory of Pondicherry CGWB, Hyderabad, pp 1-20

Dar IA, Sankar K, Dar MA (2011) Spatial assessment of groundwater quality in Mamundiyar basin, Tamil Nadu, India. Environ Monit Assess 178:437-447

Davies SN, DeWiest RJM (1966) Hydrogeology. Wiley, New York

Diaz-Barrigo F, Navarro-Quezada A, Grijalva MI, Grimaldo M, Loyola-Rodriguez JP, Ortiz MD (1997) Endemic fluorosis in Mexico. Fluoride 30:233-239

Eaton EM (1950) Significance in carbonate in irrigation water. Soil Sci 69:123-133

Edmunds M, Smedley P (2005) Fluoride in natural waters. In: Selinus $\mathrm{O}$ et al (eds) Essentials of Medical Geology, Impacts of Natural Environment on Public Health. Elsevier Academic Press, London, pp 301-329

Elhatip H, Afsin M, Kuscu L, Dirik K, Kurmac A, Kavurmac M (2003) Influences of human activities and agriculture on groundwater quality of Kayseri-Incesu-Dokuzpınar springs, central Anatolian part of Turkey. Environ Geol 44:490-494

Freeze RA, Cherry JA (1979) Groundwater. Prentice Hall, Englewood Cliffs 604

Hamilton WR, Wolley AR, Bishop AC (1982) The country life guide to minerals, rocks and fossils, 10th edn. Country Life Books, Spain
ICPS (2002) Environment Health Criteria 227: Fluorides. In: Liteplo $\mathrm{R}$, Howe $\mathrm{P}$, Malcolm $\mathrm{H}$ (eds) International Programme on Chemical Safety. World Health Organization, Geneva, p 268

IRRI (International Rice Research Institute) (2007) Rough rice production in India. http://www.irriorg/science/ricestat/data/ may2008/WRS2008-Table07pdf

Jacks G, Bhattacharya P, Chaudhary V, Singh KP (2005) Controls on the genesis of some high-fluoride groundwaters in India. Appl Geochem 20:221-228

Jalali M (2009) Geochemistry characterization of groundwater in an agricultural area of Razan, Hamadan, Iran. Environ Geol 56:1479-1488

Jeevanandam M, Kannan R, Srinivasalu S, Rammohan V (2006) Hydrogeochemistry and Groundwater Quality Assessment of Lower Part of the Ponnaiyar River Basin, Cuddalore District, South India. Environ Monit Assess 132(1-3):263-274

Jeong CH (2001) Effect of land use and urbanization on hydrochemistry and contamination of groundwater from Taejon area, Korea. J Hydrol 253:194-210

Jiang Y, Wu Y, Groves C, Yuan D, Kambesis P (2009) Natural and anthropogenic factors affecting the groundwater quality in the Nandong karst underground river system in Yunan, China. J Contam Hydrol 109:49-61

Kamble SR, Vijay R (2011) Assessment of water quality using cluster analysis in coastal region of Mumbai, India. Environ Monit Assess 178:321-332

Kruse E, Ainchil J (2003) Fluoride variations in groundwater of an area in Buenos Aires Province, Argentina. Environ Geol 44:86-89

Kumar SK, Rammohan V, Sahayam JD, Jeevanandam M (2009) Assessment of groundwater quality and hydrogeochemistry of Manimuktha River basin, Tamil Nadu, India. Environ Monit Assess 159:341-351

Lang YC, Liu CQ, Li SL, Zhao ZQ, Zhou ZH (2011) Tracing natural and anthropogenic sources of dissolved sulfate in a karst region by using major ion chemistry and stable sulfur isotopes. Appl Geochem 26:S202-S205

Lee SM, Min KD, Woo NC, Kim YJ, Ahn CH (2003) Statistical models for the assessment of nitrate contamination in urban groundwater using GIS. Environ Geol 44:210-221

Ma J, Ding Z, Wei G, Zhao H, Huang T (2009) Sources of water pollution and evolution of water quality in the Wuwei basin of Shiyang River, Northwest China. J Environ Manag 90:1168-1177

Mjengera H, Mkongo G (2003) Appropriate deflouridation technology for use in flourotic areas in Tanzania. Phys Chem Earth 28:1097-1104

Natarajan P (1982) Hydrogeological condition in Thanjavur district, Tamil Nadu. CGWB Report CGWB, Hyderabad

Pant BR (2011) Ground water quality in the Kathmandu valley of Nepal. Environ Monit Assess 178:477-485

Parkhurst DL, Appelo CAJ (1999) User's guide to PHREEQC (version 2) - a computer program for speciation, batch-reaction, one-dimensional transport, and inverse geochemical calculations USGS Water-Resources Investigations Report, 99-4259

Pritchard M, Mkandawire T, O'Neill JG (2008) Assessment of groundwater quality in shallow wells within the southern districts of Malawi. Phys Chem Earth 33:812-823

Rajamanickam GV, Subramaniyan BR, Baba M, Ramesh R, Elango L, Prithviraj M (2006) 26th December 2004 tsunami: causes, effects, remedial measures pre and post tsunami disaster management: a geoscientific perspective. New Academic Publishers, New Delhi

Rajmohan N, Elango L (2005) Nutrient chemistry of groundwater in an intensively irrigated region of Southern India. Environ Geol 47:820-830

Rajmohan N, Al-Futaisi A, Al-Touqi S (2009) Geochemical process regulating groundwater quality in a coastal region with complex 
contamination sources: Barka, Sultanate of Oman. Environ Earth Sci 59(2):385-398

Ramesh K, Elango L (2011) Groundwater quality and its suitability for domestic and agricultural use in Tondiar river basin, Tamil Nadu, India. Environ Monit Assess 184:3887-3899

Reddy NB, Prasad KSS (2003) Pyroclastic fluoride in groundwater in some parts of Tadpatri Taluk, Anantapur District, Andhra Pradesh. Indian J Environ Health 45:285-288

Richards LA (1954) Diagnosis and improvement of saline and alkali soils, Agri Hand book 60. US Dept of Agriculture, Washington, DC

Rosenthal E, Vinokurov A, Ronen D, Magaritz M, Moshkovitz S (1992) Anthropogenically induced salinization of groundwater: a case study from the Coastal Plain aquifer of Israel. J Contam Hydrol 11:149-171

Sankaran M, Natarajan P (1980) Groundwater surveys, explorations in Karaikal region and its environs, Union Territory of Pondicherry Rep H-6. CGWB, Hyderabad, India

Saxena VK, Ahmed S (2003) Inferring the chemical parameters for the dissolution of fluoride in groundwater. Environ Geol 43:731-736

Shortt HE, McRobert GR, Barnard TW, Mannadinayer AS (1937) Endemic fluorosis in Madras Presidency. Indian J Med Res 25:553-561

Sivakumar C, Elango L (2008) Assessment of water quality in Kalpakkam region, Tamil Nadu. Nat Environ Pollut Technol 7(4):687-691

Sivakumar C, Elango L (2010) Application of solute transport modeling to study tsunami induced aquifer salinity in India. J Environ Inform 15(1):33-41

Subramani T, Elango L, Damodarasamy SR (2005) Groundwater quality and its suitability for drinking and agricultural use in Chithar River Basin, Tamil Nadu, India. J Environ Geol 47(8):1099-1110

Sukhija BS, Varma VN, Nagabhushanam P, Reddy DV (1996) Differentiation of Palaeomarine and modern seawater intruded salinities in coastal groundwaters (of Karaikal and Tanjavur, India) based on inorganic inorganic chemistry, organic biomarker fingerprints and radiocarbon dating. J Hydrol 174: 173-201

Tank DK, Chandel CPS (2010) A hydrochemical elucidation of the groundwater composition under domestic and irrigated land in Jaipur City. Environ Monit Assess 166(1-4):69-77

UNDP (1971) Groundwater investigations in Tamil Nadu (phase I) United Nations Tech Rep, New York

UNESCO (2007) UNESCO water portal newsletter no 161: waterrelated diseases. http://wwwunescoorg/water/news/newsletter/ $161 \mathrm{shtml}$

United States Salinity Laboratory (1954) Diagnosis and improvement of saline and alkaline soils. US Department of Agriculture, Washington, DC

Varadaraj N, Natarajan P (1988) Design of groundwater extraction structures Thanjavur district. Bhujal News 4:15-19

Vengosh E, Rosenthal E (1994) Saline groundwater in Israel; its bearing on the water crisis in the country. J Hydrol 156:389-430

Vijay R, Khobragade P, Mohapatra PK (2011) Assessment of groundwater quality in Puri City, India: an impact of anthropogenic activities. Environ Monit Assess 177:409-418

Wang LFM, Huang JZ (1995) Outline of control practice of endemic fluorosis in China. Soc Sci Med 41:1191-1195

WHO (1993) Guidelines for drinking water quality, recommendations, 2nd edn. World Health Organization, Geneva

WHO (1994) Fluorides and Oral Health, (Technical Report Series No 846). World Health Organisation, Geneva

WHO (2009) Potassium in drinking-water background document for development of WHO guidelines for drinking-water quality WHO/HSE/WSH/09.01/7

WRC (2001) Distribution of fluoride-rich groundwater in Eastern and Mogwase region of Northern and North-west province; WRC Report No 526/1/0111-985, Pretoria 